\title{
Thermodynamics of Ylide Formation from Carbenes and Carbonyl Compounds
}

\author{
Josefredo R. Pliego Jr., and Wagner B. De Almeida \\ Laboratório de Química Computacional e Modelagem Molecular (LQC-MM); \\ Departamento de Química, ICEx, Universidade Federal de Minas Gerais (UFMG), \\ 31270-901 Belo Horizonte - MG, Brazil
}

Received: November 28, 1997

\begin{abstract}
Os parâmetros termodinâmicos para a reação dos carbenos $\mathrm{CH}_{2}$ (simpleto e tripleto), $\mathrm{CF}_{2} \mathrm{e}$ $\mathrm{C}(\mathrm{OH})_{2}$ com formaldeído, acetaldeído e acetona foram determinados através de cálculos ab initio de alto nível. O metileno simpleto forma ilídeos estáveis com os três compostos carbonílicos, tendo um $\Delta \mathrm{H}^{\mathrm{O}}$ de reação de $-41.6 \mathrm{kcal} / \mathrm{mol},-40.0 \mathrm{kcal} / \mathrm{mol}$ (isômero E), $-44.5 \mathrm{kcal} / \mathrm{mol}$ (isômero Z) e $-40.8 \mathrm{kcal} / \mathrm{mol}$, respectivamente. O metileno tripleto também forma ilídeo com formaldeído, com um $\Delta \mathrm{E}$ de reação de $-15.7 \mathrm{kcal} / \mathrm{mol}$, resultando que a formação do ilídeo neste estado eletrônico é reversível. Já os carbenos $\mathrm{CF}_{2}$ e $\mathrm{C}(\mathrm{OH})_{2}$ formam ilídeos com formaldeído com um $\Delta \mathrm{H}^{\mathrm{o}}$ de 13.0 $\mathrm{kcal} / \mathrm{mol} \mathrm{e} 22.0 \mathrm{kcal} / \mathrm{mol}$, e um $\Delta \mathrm{G}^{\mathrm{o}}$ de $25.3 \mathrm{kcal} / \mathrm{mol} \mathrm{e} 34.0 \mathrm{kcal} / \mathrm{mol}$, respectivamente. Estes valores positivos de energia livre indicam que estes ilídeos não devem ser formados a partir de carbenos e carbonilas, e possivelmente estes carbenos reagem com aldeídos e cetonas por cicloadição 1,2.
\end{abstract}

Thermodynamic parameters for the reaction of $\mathrm{CH}_{2}$ (singlet and triplet), $\mathrm{CF}_{2}$ and $\mathrm{C}(\mathrm{OH})_{2}$ carbenes with formaldehyde, acetaldehyde and acetone, forming carbonyl ylides, were determined using high level ab initio molecular orbital calculations. Singlet methylene forms a stable ylide with the three carbonyl compounds, with a $\Delta \mathrm{H}^{\mathrm{O}}$ of $-41.6 \mathrm{kcal} / \mathrm{mol},-40.0 \mathrm{kcal} / \mathrm{mol}$ (E isomer), -44.5 $\mathrm{kcal} / \mathrm{mol}$ ( $\mathrm{Z}$ isomer) and $-40.8 \mathrm{kcal} / \mathrm{mol}$, respectively. Triplet methylene also forms a ylide with formaldehyde with a $\Delta \mathrm{E}$ of $-15.7 \mathrm{kcal} / \mathrm{mol}$, resulting in the triplet ylide being formed reversibly. For the reaction with formaldehyde, the $\mathrm{CF}_{2}$ and $\mathrm{C}(\mathrm{OH})_{2}$ carbenes have a positive $\Delta \mathrm{H}^{\mathrm{o}}$ of $13.0 \mathrm{kcal} / \mathrm{mol}$ and $22.0 \mathrm{kcal} / \mathrm{mol}$, and $\Delta \mathrm{G}^{\mathrm{o}}$ of $25.3 \mathrm{kcal} / \mathrm{mol}$ and $34.0 \mathrm{kcal} / \mathrm{mol}$, respectively. Due to its unfavorable free energy of formation, and the potential competition of direct 1,2 cycloaddition of carbene to the $\mathrm{C}=\mathrm{O}$ group, $\mathrm{CF}_{2}$ and $\mathrm{C}(\mathrm{OH})_{2}$ should not react with carbonyl compounds forming ylides.

Keywords: ylide formation, carbene-carbonyl compounds, ab initio, thermodynamics

\section{Introduction}

Carbonyl ylides are useful reactive intermediates with potential utilization in organic synthesis ${ }^{1}$. These species have biradical characteristics ${ }^{2,3}$ and are able to perform 1,3 cycloaddition reactions with dipolarophiles such as $\mathrm{C}=\mathrm{C}$ and $\mathrm{C}=\mathrm{O}$ (Scheme 1). They can be generated by thermal or photochemical ring opening of oxiranes ${ }^{4}$, or also by reactions of carbenes with carbonyl compounds (Scheme 2). The second case is especially interesting, and has been the subject of many studies ${ }^{5-17}$. For a long time, it was thought that carbenes react with carbonyls forming ylides only, but recently we have shown through high level $a b$ initio calculations that direct 1,2 cycloaddition can effectively com-

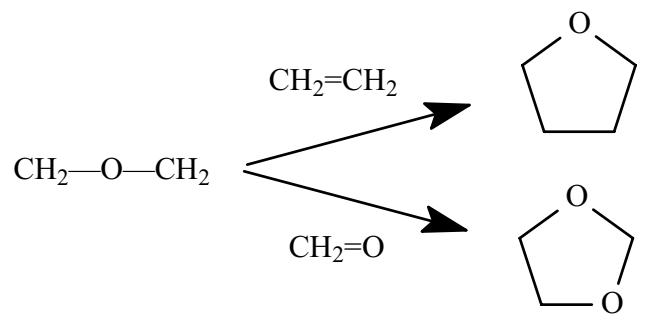

Scheme 1. 

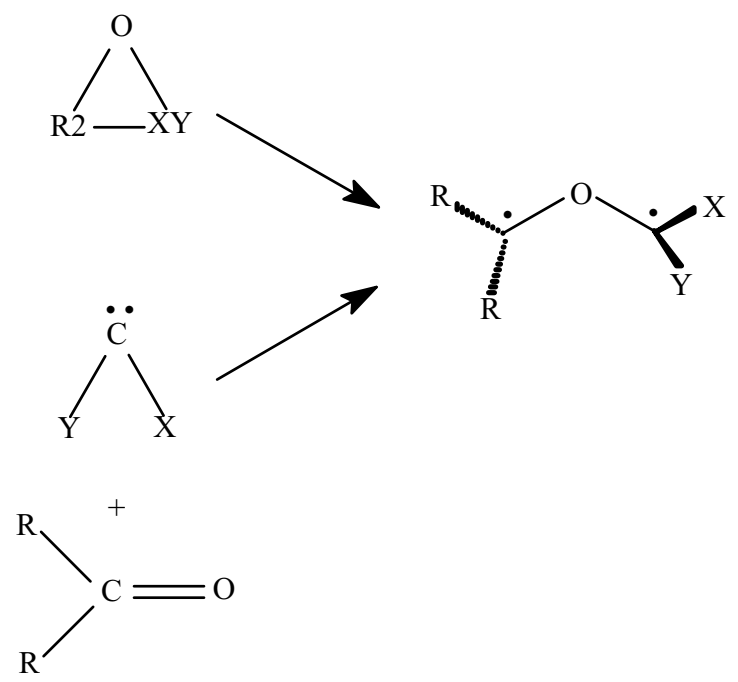

Scheme 2.

pete with ylide formation ${ }^{2}$. This is an important result because the parallel pathway can reduce substantially the ylide formation, producing a low 1,3 cycloaddition yield. Also, the thermodynamic stability of carbonyl ylides in relation to fragmentation, and even their existence, is heavily dependent on the nature of the carbene, i.e. the nature of the substituting groups bonded to the carbene center. Some previous theoretical studies support this assertion ${ }^{18}$. Thus, the thermodynamic stability of ylides is an important parameter in order to determine the ability of a carbene to form a carbonyl ylide, and it is probably related to the height of the barrier to ylide formation.

In this work, we report thermodynamic properties of ylide formation from some representative carbenes and carbonyl compounds obtained using ab initio molecular orbital calculations. Then we have discussed the implication of the present result to the reaction mechanism of carbenes with carbonyls. A comparison with experimental data that is available was made. The chosen carbenes were $\mathrm{CH}_{2}$ (singlet and triplet), $\mathrm{CF}_{2}$ and $\mathrm{C}(\mathrm{OH})_{2}$, which represent an electrophilic carbene, a relatively inert carbene and a nucleophilic carbene, respectively. The carbonyl compounds utilized were formaldehyde, acetaldehyde and acetone.

\section{Calculations}

Geometries of ylides, carbenes and carbonyl compounds were obtained by energy minimization using Second Order Moller-Plesset Perturbation Theory (MP2) level of electron correlation. The Dunning's DZ+P(d) basis set ${ }^{19}$, which corresponds to DZ basis set for hydrogen and DZP basis set for the other atoms, was used. Figure 1 presents the obtained geometries. Harmonic frequencies were also calculated at the MP2/DZ+P(d) level. In order to obtain accurate thermodynamic properties, single point energy calculations were performed at the MP4 and $\operatorname{CCSD}(\mathrm{T})$ levels of theory, and we have used more extended basis set $\left(6-311 \mathrm{G}^{* *}\right.$ and $\left.6-311+\mathrm{G}(2 \mathrm{df}, \mathrm{p})\right)$. Statistical thermodynamic calculations on $a b$ initio data were performed to
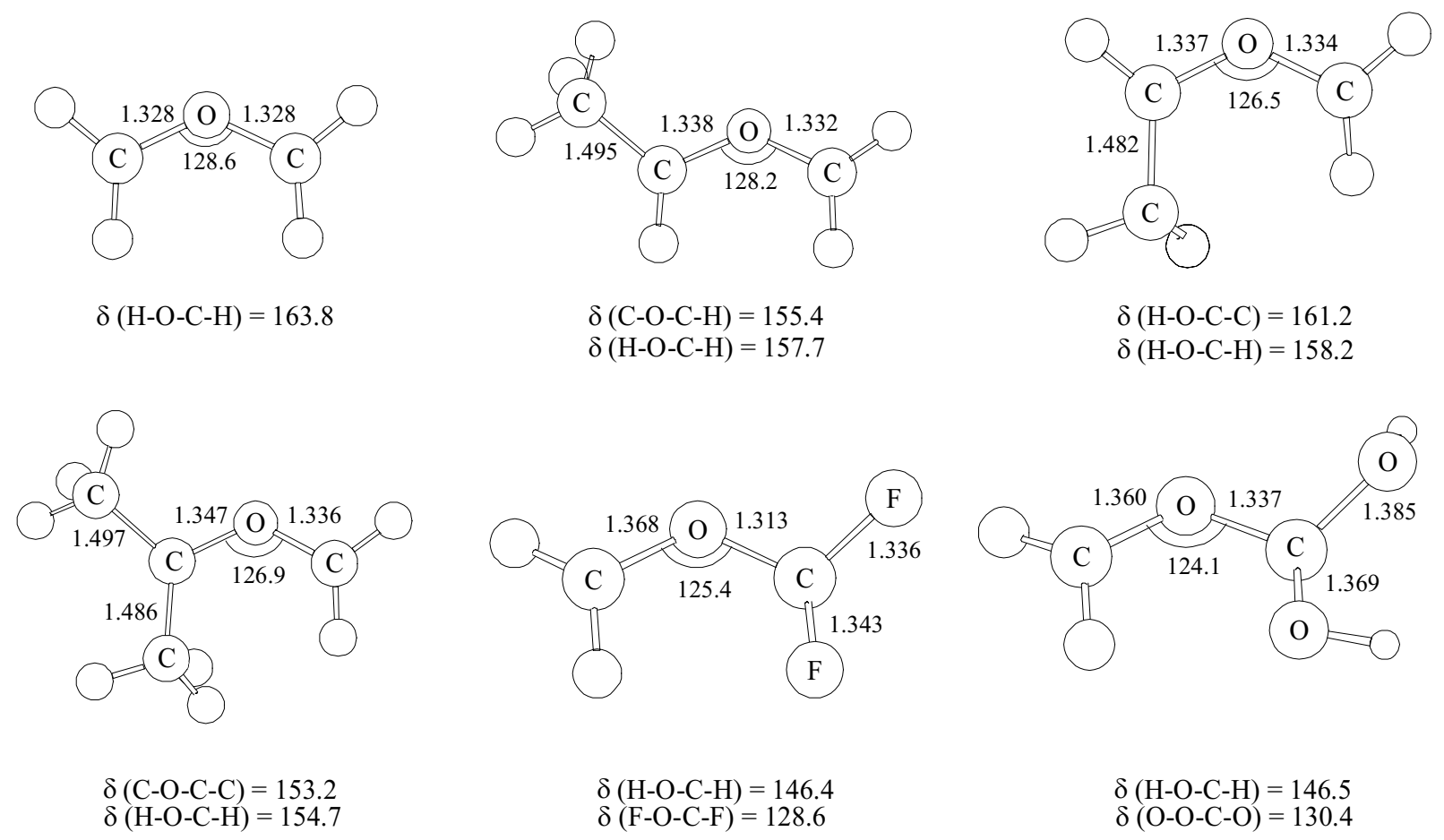

Figure 1. 
obtain $\Delta \mathrm{H}, \Delta \mathrm{S}$ and $\Delta \mathrm{G}$ for ylide formation. The results are presented in Tables 1 to 3 . We have used the symbols ${ }^{\circ}$ and * to represent standard states of $1 \mathrm{~atm}$ of pressure and 1 $\mathrm{mol} / \mathrm{L}$ of concentration, respectively. Standard enthalpy and entropy properties at $1 \mathrm{~mol} / \mathrm{L}$ are defined by the expressions $\Delta \mathrm{S}^{*}=-\partial \Delta \mathrm{G}^{*} / \partial \mathrm{T}$ and $\Delta \mathrm{H}^{*}=\Delta \mathrm{G}^{*}+\mathrm{T} \Delta \mathrm{S}^{*}$. All calculations were carried out with the GAMESS ${ }^{20}$ and GAUSSIAN $94^{21}$ ab initio programs.

\section{Results and Discussion}

\section{Ylides of singlet and triplet methylene with formaldehyde}

The molecular structure of the carbonyl ylide formed from methylene (singlet) and formaldehyde is in Fig. 1. Some important geometrical parameters are presented, which can be compared with values of a previous work by Schaefer et al. ${ }^{3}$ The ylide has $\mathrm{C}_{2}$ symmetry, with the $\mathrm{CH}_{2}$ groups in a pyramidal form. The formation energies calculated using various levels of theory and the thermodynamic parameters are in Table 1. In accordance with our previous report for 1,1-dichloro carbonyl ylide, a high level of electron correlation is necessary to obtain accurate reaction energies. Our best level of calculation, i.e. $\operatorname{CCSD}(\mathrm{T}) / 6-$ $311+\mathrm{G}(2 \mathrm{df}, \mathrm{p})$, predicts a $\Delta \mathrm{H}^{\circ}$ value of $-41.6 \mathrm{kcal} / \mathrm{mol}$, indicating a very exothermic reaction. The $\Delta \mathrm{G}^{\circ}$ parameter is $-30.8 \mathrm{kcal} / \mathrm{mol}$, meaning that carbonyl ylide formation is an irreversible process. These data are in contradiction with the report of Prakash et al. ${ }^{12}$, which suggest that this carbonyl ylide is formed reversibly ${ }^{12}$. This point will be discussed later in the text.

Methylene presents a low singlet-triplet splitting, with the triplet state $\left(\mathrm{T}_{0}\right)$ being more stable than the singlet state $\left(\mathrm{S}_{1}\right)$ by $9.1 \mathrm{kcal} / \mathrm{mol}$ (value taken from Ref. 28). Many experiments for carbene generation use a photochemical process and the carbenes can be formed in singlet or triplet states. When generated in the singlet state, subsequent intersystem crossing to the triplet can occur. An important question is "In which electronic state does methylene react with carbonyl?" It depends on which state it is generated, the intersystem crossing rate, and the stability and the rate of carbonyl ylide formation for each state. Therefore, knowledge of the relative energy between triplet and singlet states of carbonyl ylides and carbenes are important data, and we have reported the respective calculations in Table 1 . Our best value is $15.2 \mathrm{kcal} / \mathrm{mol}$ for singlet-triplet splitting of the carbonyl ylide, with the singlet being the most stable state. Combining this data with $-9.1 \mathrm{kcal} / \mathrm{mol}$ for singlet-triplet splitting in methylene, we can calculate the reaction energy for carbonyl ylide formation in the triplet state, which is $-15.7 \mathrm{kcal} / \mathrm{mol}$ (Table 1). A general

Table 1. Results of ab initio calculations of carbonyl ylide formation from formaldehyde and singlet $\left(\mathrm{S}_{1}\right)$ and triplet $\left(\mathrm{T}_{0}\right)$ methylene. Triplet formation energy was calculated by using singlet formation energy, and singlet-triplet splitting of the carbonyl ylide and methylene (-9.1 kcal/mol, taken from Ref. 28). The symbols ${ }^{\circ}$ and $*$ correspond to a standard state of $1 \mathrm{~atm}$ of pressure and $1 \mathrm{~mol} / \mathrm{L}$ of concentration (see text). $\mathrm{T}=298.15 \mathrm{~K}$. Units are in kcal $/ \mathrm{mol}$.

\begin{tabular}{|c|c|c|c|}
\hline & $\mathrm{CH}_{2}-\mathrm{O}-\mathrm{CH}_{2}\left(\mathrm{~S}_{\mathrm{o}}\right)$ & $\mathrm{CH}_{2}-\mathrm{O}-\mathrm{CH}_{2}\left(\mathrm{~T}_{1}\right)$ & $\Delta\left(\mathrm{T}_{1}-\mathrm{S}_{0}\right)^{\mathrm{a}}$ \\
\hline \multicolumn{4}{|c|}{ ab initio calculations } \\
\hline \multicolumn{4}{|c|}{$\mathrm{DZ}+\mathrm{P}(\mathrm{d})$} \\
\hline MP2 & -53.1 & - & 18.0 \\
\hline$\Delta \mathrm{ZPE}^{\mathrm{b}}$ & 6.3 & - & -0.8 \\
\hline \multicolumn{4}{|c|}{$6-311(d, p)$} \\
\hline MP2 & -52.2 & - & 18.6 \\
\hline MP4(SDQ) & -38.8 & - & 8.3 \\
\hline MP4 & -46.6 & - & 17.0 \\
\hline $\operatorname{CCSD}(\mathrm{T})$ & -44.2 & - & 14.9 \\
\hline \multicolumn{4}{|c|}{$6-311+G(2 d f, p)$} \\
\hline MP2 & -54.7 & - & 20.1 \\
\hline MP4 & -48.7 & - & 18.1 \\
\hline $\operatorname{CCSD}(T)^{\mathrm{c}}$ & -46.3 & - & 16.0 \\
\hline \multicolumn{4}{|c|}{ thermodynamic properties } \\
\hline$\Delta \mathrm{E}^{\mathrm{d}}$ & -40.0 & -15.7 & 15.2 \\
\hline$\Delta \mathrm{H}^{\circ}$ & -41.6 & - & - \\
\hline$-\mathrm{T} \Delta \mathrm{S}^{\circ}$ & 10.8 & - & - \\
\hline$\Delta \mathrm{G}^{\circ}$ & -30.8 & - & - \\
\hline$\Delta \mathrm{H}^{*}$ & -41.0 & - & - \\
\hline -T $\Delta \mathrm{S}^{*}$ & 8.3 & - & - \\
\hline$\Delta \mathrm{G}^{*}$ & -32.7 & - & - \\
\hline
\end{tabular}

${ }^{\mathrm{a}}$ Triplet minus singlet carbonyl ylide energy; ${ }^{\mathrm{b}}$ Zero point vibrational energy contribution; ${ }^{\mathrm{c}}$ Obtained by additivity approximation; ${ }^{\mathrm{d}}$ Classical energy plus $\triangle \mathrm{ZPE}$. 
Table 2. Results of $a b$ initio calculations of substituted carbonyl ylide formation from methylene, acetaldehyde and acetone. The symbols ${ }^{\circ}$ and $*$ correspond to a standard state of 1 atm of pressure and $1 \mathrm{~mol} / \mathrm{L}$ of concentration (see text). The values in parentheses correspond to experimental data. $\mathrm{T}$ $=298.15 \mathrm{~K}$. Units are in $\mathrm{kcal} / \mathrm{mol}$.

\begin{tabular}{|c|c|c|c|}
\hline & $\mathrm{E}-\mathrm{MeCH}-\mathrm{O}-\mathrm{CH}_{2}$ & $\mathrm{Z}-\mathrm{MeCH}-\mathrm{O}-\mathrm{CH}_{2}$ & $(\mathrm{Me})_{2} \mathrm{C}-\mathrm{O}-\mathrm{CH}_{2}$ \\
\hline \multicolumn{4}{|c|}{ ab initio calculations } \\
\hline \multicolumn{4}{|c|}{$\mathrm{DZ}+\mathrm{P}(\mathrm{d})$} \\
\hline MP2 & -48.7 & -53.1 & -50.6 \\
\hline$\Delta \mathrm{ZPE}^{\mathrm{a}}$ & 6.2 & 6.4 & 6.9 \\
\hline \multicolumn{4}{|c|}{$6-31 G(d)$} \\
\hline MP2 & -49.7 & -53.6 & -51.6 \\
\hline MP4(SDQ) & -36.6 & -40.2 & -36.7 \\
\hline MP4 & -44.3 & -47.6 & -45.1 \\
\hline \multicolumn{4}{|c|}{$6-311+G(2 d f, p)$} \\
\hline MP2 & -50.2 & -55.2 & -52.8 \\
\hline $\mathrm{MP}^{\mathrm{b}}$ & -44.8 & -49.2 & -46.3 \\
\hline \multicolumn{4}{|c|}{ thermodynamic properties } \\
\hline$\Delta \mathrm{E}^{\mathrm{c}}$ & -38.6 & -42.8 & -39.4 \\
\hline$\Delta \mathrm{H}^{\circ}$ & -40.0 & -44.5 & -40.8 \\
\hline$-\mathrm{T} \Delta \mathrm{S}^{\circ}$ & 11.1 & 11.6 & 11.3 \\
\hline$\Delta \mathrm{G}^{\circ}$ & -28.9 & -32.9 & -29.5 \\
\hline$\Delta \mathrm{H}^{*}$ & -39.4 & -43.9 & $-40.2(-45.4 \pm 9.9)^{\mathrm{d}}$ \\
\hline$-\mathrm{T} \Delta \mathrm{S}^{*}$ & 8.6 & 9.1 & 8.8 \\
\hline$\Delta \mathrm{G}^{*}$ & -30.8 & -34.8 & -31.4 \\
\hline
\end{tabular}

${ }^{\mathrm{a}}$ Zero point vibrational energy contribution; ${ }^{\mathrm{b}}$ Obtained by additivity approximation; ${ }^{\mathrm{c}}$ Classical energy plus $\Delta$ ZPE. ${ }^{\mathrm{d}}-$ Experimental value taken from Ref. 8 .

Table 3. Results of $a b$ initio calculations of substituted carbonyl ylide formation from formaldehyde and dichlorocarbene, difluorocarbene and dihydroxycarbene. The symbols ${ }^{\circ}$ and $*$ correspond to a standard state of $1 \mathrm{~atm}$ of pressure and $1 \mathrm{~mol} / \mathrm{L}$ of concentration $(\mathrm{see}$ text). $\mathrm{T}=298.15 \mathrm{~K}$. Units are in $\mathrm{kcal} / \mathrm{mol}$.

\begin{tabular}{|c|c|c|c|}
\hline & $\mathrm{CH}_{2}-\mathrm{O}-\mathrm{CCl}_{2}{ }^{\mathrm{a}}$ & $\mathrm{CH}_{2}-\mathrm{O}-\mathrm{CF}_{2}$ & $\mathrm{CH}_{2}-\mathrm{O}-\mathrm{C}(\mathrm{OH})_{2}$ \\
\hline \multicolumn{4}{|c|}{$a b$ initio calculations } \\
\hline \multicolumn{4}{|c|}{$\mathrm{DZ}+\mathrm{P}(\mathrm{d})$} \\
\hline MP2 & - & 6.7 & 16.0 \\
\hline$\Delta \mathrm{ZPE}^{\mathrm{b}}$ & - & 4.4 & 3.2 \\
\hline \multicolumn{4}{|c|}{ DZP } \\
\hline MP2 & - & 6.9 & 15.5 \\
\hline MP4(SDQ) & - & 18.1 & 28.4 \\
\hline MP4 & - & 10.0 & 19.7 \\
\hline \multicolumn{4}{|c|}{ thermodynamic properties } \\
\hline$\Delta \mathrm{E}^{\mathrm{c}}$ & -10.3 & 14.4 & 22.9 \\
\hline$\Delta \mathrm{H}^{\circ}$ & -11.5 & 13.0 & 22.0 \\
\hline$-\mathrm{T} \Delta \mathrm{S}^{\circ}$ & 11.8 & 12.3 & 12.0 \\
\hline$\Delta \mathrm{G}^{\circ}$ & 0.4 & 25.3 & 34.0 \\
\hline$\Delta \mathrm{H}^{*}$ & -10.9 & 13.6 & 22.6 \\
\hline$-\mathrm{T} \Delta \mathrm{S} *$ & 9.4 & 9.8 & 9.5 \\
\hline$\Delta \mathrm{G}^{*}$ & -1.5 & 23.4 & 32.1 \\
\hline
\end{tabular}

${ }^{\mathrm{a}}$ Taken from Ref. $2{ }^{\mathrm{b}}{ }^{\mathrm{Z}}$ Zero point vibrational energy contribution; ${ }^{\mathrm{c}}$ Classical energy plus $\Delta \mathrm{ZPE}$.

view of the process in both electronic states is in Fig. 2 that presents an energy diagram for carbonyl ylide formation in singlet and triplet states. These data show that the triplet ylide is less stable than the singlet, and possibly dissocia- ting into its fragments easier, i.e. its formation is relatively reversible. This finding led us to inquire into the possibility that Prakash et al. ${ }^{12}$ has observed the reaction of the triplet state instead of the singlet, because for the former the ylide 
may undergo a revessible reaction, while for the singlet the reaction is irreversible.

Another interesting point is the crossing between singlet and triplet potential energy surfaces, indicated in Fig. 2. The crossing could occur along the reaction pathway, resulting in intersystem crossing between the states. There is a possibility that the system moving along the triplet surface jumps to the singlet surface, resulting in the singlet ylide. In this case, the ylide formation would be practically irreversible.

\section{Ylides of methylene with acetaldehyde and acetone}

Reaction of methylene with acetaldehyde can form 1-methyl carbonyl ylide in two isomeric forms: $\mathrm{E}$ and $\mathrm{Z}$. Figure 1 shows the corresponding structures of each species. These isomers are as stable as the parent carbonyl ylide, so that the methyl group has a small effect on the ylide stability. Almost the same value for the formation energy is also observed for 1,1-dimethyl carbonyl ylide. However, the two isomers have a reasonable difference in stability, the $\mathrm{Z}$ isomer being more stable than the $\mathrm{E}$ isomer by $4.0 \mathrm{kcal} / \mathrm{mol}\left(\Delta \mathrm{G}^{*}\right)$. This result came as a surprise for us because we were expecting the $\mathrm{E}$ isomer to be the most stable, as it should have minor steric hindrance. An experimental value of $\Delta \mathrm{H}^{*}$ for 1,1-dimethyl carbonyl ylide formation obtained by photoacoustic calorimetry is available ${ }^{8}$, and it is given in Table 2. The experimental value of -45.4 $\pm 9.9 \mathrm{kcal} / \mathrm{mol}$ is in good agreement with our high level $a b$ initio result of $-40.2 \mathrm{kcal} / \mathrm{mol}$. Due to the large uncertainty in the experimental data, we suggested that our calculated $\Delta H^{*}$ is the more correct value.

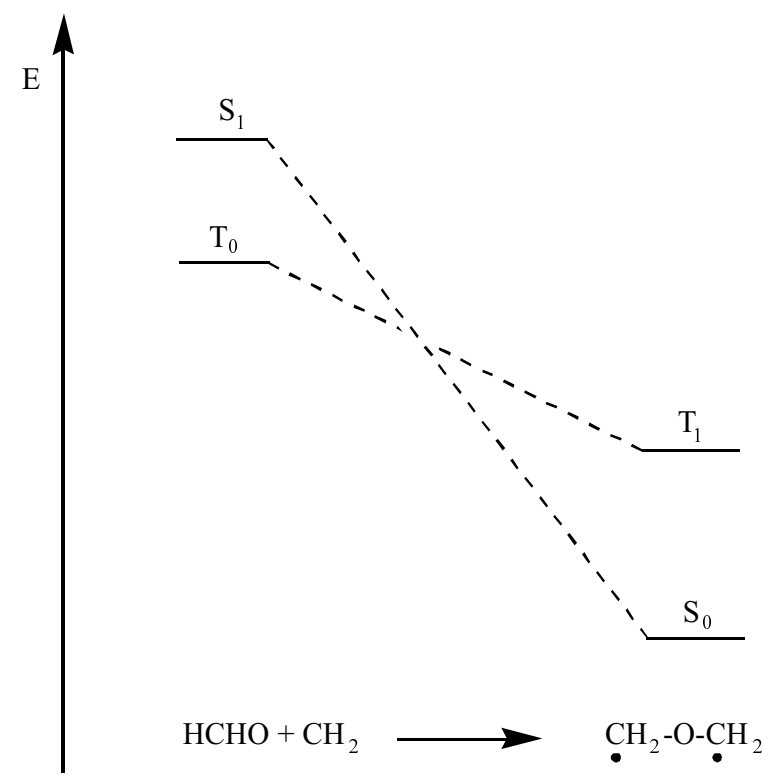

Figure 2.

\section{Ylides of difluorocarbene and dihydroxycarbene with formaldehyde}

Among the several carbene molecules, $\mathrm{CF}_{2}$ is one of the least reactive. Its relative inertness leads it to be a selective reactant. In the present case, difluorocarbene reacts with formaldehyde endothermically, having a $\Delta \mathrm{H}^{\circ}$ of 13.0 $\mathrm{kcal} / \mathrm{mol}$. Consequently, the ylide formation is not spontaneous with a $\Delta \mathrm{G}^{\circ}$ of $25.3 \mathrm{kcal} / \mathrm{mol}$. The same behavior is found for $\mathrm{C}(\mathrm{OH})_{2}$. The respective $\Delta \mathrm{H}^{\circ}$ and $\Delta \mathrm{G}^{\circ}$ values for ylide formation are $22.0 \mathrm{kcal} / \mathrm{mol}$ and $34.0 \mathrm{kcal} / \mathrm{mol}$ respectively. Another similarity between these species is the pyramidal form of the $\mathrm{CH}_{2}$ and $\mathrm{CX}_{2}$ groups that is more accentuated in these species than in the other ylides (see Fig. 1).

The effect of the $\mathrm{F}$ and $\mathrm{OH}$ groups on ylide stability is very strong. It can be better observed in Fig. 3, which also includes the formation energy of 1,1-dichloro carbonyl ylide and the other ylides studied in this work. The diagram shows that ylides range from very stable species, as the parent carbonyl ylide, to very unstable species such as dihydroxy carbonyl ylide.

Difluorocarbene reacts with olefins forming cyclopropanes and the related activation energy was calculated by Wong et l. $^{22}$ to be $10.5 \mathrm{kcal} / \mathrm{mol}$. We should expect a similar value for carbene 1,2 cycloaddition to carbonyl, when this pathway competes efficiently with ylide formation $^{2}$. Because 1,1-difluoro carbonyl ylide is formed with a positive energy in relation to its fragments, the activation energy for ylide formation is at least $14.5 \mathrm{kcal} / \mathrm{mol}$. These observations indicate that the probable pathway for $\mathrm{CF}_{2}$ to react with carbonyl compounds is via 1,2 cycloaddition, and ylide formation should not play an important role. Nevertheless, $\mathrm{Hu}$ et $a l^{23}$ has used the ylide formation mechanism to explain the deoxygenation of carbonyl compounds by $\mathrm{CF}_{2}$. In the light of the present results, we think that this mechanism should be revised.

Nucleophilic carbenes have been the object of recent interest in synthetic aplications ${ }^{24-27}$. Dialkoxycarbenes generally react by nucleophilic attack to electron deficient

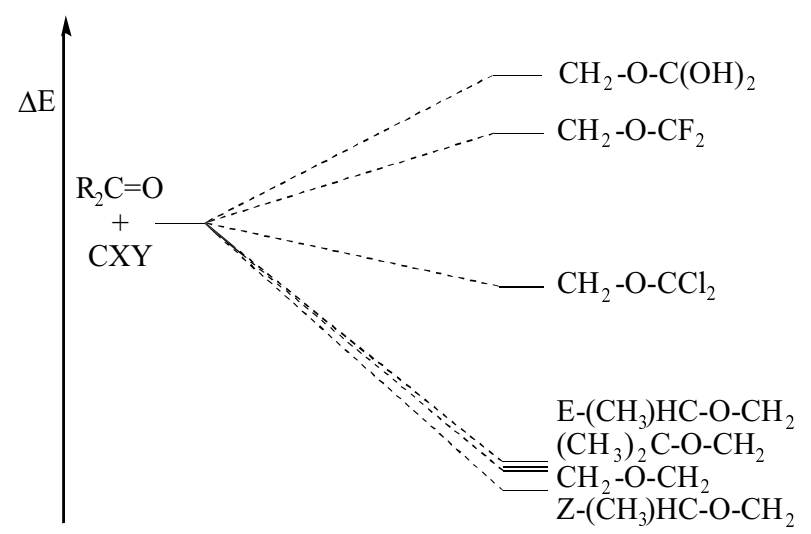

Figure 3. 
centers, and in the case of carbonyls, the most probable reaction mechanism is 1,2 cycloaddition to the $\mathrm{C}=\mathrm{O}$ bond. When an olefin is the reactant, the barrier is about 20.5 $\mathrm{kcal} / \mathrm{mol}$, calculated by MR-MP2/6-31G* level of theory for $\mathrm{C}(\mathrm{OH})_{2}$ adding to ethylene. Due to the greater electrondeficiency of the carbonyl carbon, we should expect a lower barrier for 1,2 cycloaddition to $\mathrm{C}=\mathrm{O}$. Considering that the energy for 1,1-dihydroxy carbonyl ylide formation is $22.9 \mathrm{kcal} / \mathrm{mol}$, we can dismiss ylide formation as a possible reaction pathway for $\mathrm{C}(\mathrm{OH})_{2}$ adding to a carbonyl. So, $\mathrm{C}(\mathrm{OH})_{2}$ should react with carbonyl compounds via 1,2 cycloaddition although this reaction could be slow.

\section{Conclusion}

Carbonyl ylides have a great range of stability in relation to carbenes and carbonyl fragments. Methylene in the singlet and triplet state forms a stable ylide with formaldehyde, the former irreversibly, and the later reversibly. In addition, methylene forms ylides with acetaldehyde and acetone having about the same stability order as with formaldehyde. Difluorocarbene and dihydroxycarbene do not form a stable ylide with formaldehyde. Rather, the ylide formation has a positive $\Delta \mathrm{H}^{\circ}$ and $\Delta \mathrm{G}^{\circ}$. Thus, these carbenes should react with carbonyls via 1,2 cycloaddition, forming substituted oxiranes.

\section{Acknowledgments}

We would like to thank the Consellho Nacional de Desenvolvimento Científico e Tecnológico (CNPq), the Fundação de Amparo à Pesquisa do Estado de Minas Gerais (FAPEMIG) and the Programa de Apoio ao Desenvolvimento Científico e Tecnológico (PADCT-II) for supporting this research project.

\section{References}

1. Padwa, A..; Hornbuckle, S. F. Chem. Rev. 1991, 91, 263.

2. Pliego Jr., J.R.; De Almeida, W.B. J. Chem. Phys. 1997, 106, 3582.

3. Yamaguchi, Y.; Schaefer III, H.F.; Alberts, L. J. Am. Chem. Soc. 1993, 115, 5790.

4. Kumar, C.V.; Chattopadhyay, S.K.; Das, P.K. J. Phys. Chem. 1984, 88, 5639.

5. Platz, M.S.; Olson, D.R.; J. Phys. Org. Chem. 1996, 9, 689 .

6. Chateauneuf, J.E.; Liu, M.T.H. J. Am. Chem. Soc. 1991, 113, 6585.

7. Bonneau, R.; Liu, M.T.H. J. Am. Chem. Soc. 1990 , $112,744$.

8. LaVilla, J.A.; Goodman, J.L. Tetrahedron Lett. 1988, 29, 2623.

9. Soudararajan, N.; Jackson, J.E.; Platz, M.S.; Liu, M.T.H. Tetrahedron Lett. 1988, 29, 3419.
10. Liu, M.T.H.; Soundarajan, N.; Anand, S.M.; Ibata, T. Tetrahedron Lett. 1987, 28, 1011.

11. Ibata, T; Liu, M.T.H.; Toyoda, J. Tetrahedron Lett. 1986, 27, 4383.

12. Prakash, G.K.S.; Ellis, R.W.; Felberg, J.D.; Olah, G.A. J. Am. Chem. Soc. 1986, 108, 1341.

13. Barcus, R.L.; Hadel, L.M.; Johnston, L.J.; Platz, M.S.; Savino, T.G.; Scaiano, J.C. J. Am. Chem. Soc. 1986, $108,3928$.

14. Gisch, J.F.; Landgrebe, J.A. J. Org. Chem. 1985, 50, 2050.

15. Martin, C.W.; Gill, H.S.; Landgreb, J.A. J. Org. Chem. 1983, 48, 1898.

16. Huan, Z.; Landgrebe, J.A.; Peterson, K. J. Org. Chem. 1983, 48, 4519.

17. Martin, C.W.; Lund, P.R.; Rapp, E.; Landgreb, J.A. J. Org. Chem. 1978, 43, 1071.

18. Houk, K.N.; Rondan, N.G.; Santiago, C.; Gallo, C.J.; Gandour, R.W.; Griffin, G.W. J. Am. Chem. Soc. 1980, $102,1504$.

19. Dunning, T.H.; Hay, P.J. In Methods of electronic structure theory, Schaefer III, H.F., Ed., Plenum Press, New York, 1977.

20. Schmidt, M.W.; Baldridge, K.K.; Boatz, J.A.; Elbert, S.T.; Gordon, M.S.; Jensen, J.H.; Koseki, S.; Matsunaga, N.; Nguyen, K.A.; Su, S.; Windus, T.L.; Dupuis, M.; Montgomery Jr., J.A J. Comp. Chem. 1993, 14, 1347.

21. Gaussian 94, Revision D.2, Frisch, M.J.; Trucks, G.W.; Schlegel, H.B.; Gill, P.M.W.; Johnson, B.G.; Robb, M.A.; Cheeseman, J.R.; Keith, T.; Petersson, G.A.; Montgomery, J.A.; Raghavachari, K.; Al-Laham, M.A.; Zakrzewski, V.G.; Ortiz, J.V.; Foresman, J.B.; Cioslowski, J.; Stefanov, B.B.; Nanayakkara, A.; Challacombe, M.; Peng, C.Y.; Ayala, P.Y.; Chen, W.; Wong, M.W.; Andres, J.L.; Replogle, E.S.; Gomperts, R.; Martin, R.L.; Fox, D.J.; Binkley, J.S.; Defrees, D.J.; Baker, J.; Stewart, J.P.; Head-Gordon, M.; Gonzalez, C.; Pople, J.A. Gaussian, Inc., Pittsburgh PA, 1995.

22. Wong, C.; Cheung, C.; Ma, N.; Li, W. J. Chem. Research (S) 1993, 32.

23. Hu, C.; Qing, F.; Shen, C. J. Chem. Soc. Perkin Trans. 1 1993, 335.

24. Couture, P.; Pole, D.L.; Warkentin, J. J. Chem. Soc., Perkin Trans. 2 1997, 1565.

25. Enders, D.; Breuer, K.; Runsink, J.; Teles, J.H. Liebigs Ann. 1996, 2019.

26. Rigby, J.H.; Cavezza, A.; Ahmed, G. J. Am. Chem. Soc. 1996, 118, 12848.

27. Pole, D.L.; Warkentin, J. Liebigs Ann. 1995, 1907.

28. Bauschlicher Jr., C.W.; Langhoff, S.R. J. Chem. Phys. 1987, 87, 387. 